virtuelle Konferenz der Ukrainistik "Dialog der Sprachen - Dialog der Kulturen. Die Ukraine aus globaler Sicht". Internationale virtuelle Konferenz der Ukrainistik - Мюнхен, Університет Людвіта-Максиміліана (LudwigMaximilians-Universität München). URL: http://www.ukrainistikkonferenz.slavistik.lmu.del

10. Смольницька О. Переклад сонета на прикладі трьох хвиль українського неокласицизму: виклики і невідкриті тексти. Поетичні та віршознавчі заповіти Ігоря Качуровського: До 100-річчя від дня народження: Всеукраӥнський віршознавчий семінар. Київ. 28-29 вересня 2018 року. К.: Видавничий дім Дмитра Бураго, 2018. С. 83-102.

11. Стріха М. Улюблені переклади. Вид. 2-ге, випр. і доповнене. К. : Пенмен, 2017. 770 с.

DOI https://doi.org/10.30525/978-9934-588-90-7-66

\title{
ПЕРЕКЛАДАЦЬКИЙ АНАЛІЗ ТРАНСФОРМАЦІЙ: ЧЛЕНУВАННЯ ТА ОБ'СДНАННЯ РЕЧЕНЬ ПРИ ПЕРЕКЛАДІ РОМАНУ “ТНЕ LORD OF THE RINGS" ДЖОНА РОНАЛЬДА РУЕЛА
}

\section{Тарасюк А. М.}

асистент кафедри романо-германської філології та перекладу Білочерківський начіональний аграрний університет м. Біла Церква, Київська область, Україна

Необхідність застосування синтаксичних трансформацій у перекладі, як правило, зумовлена особливостями актантної структури речень мови оригіналу та мови перекладу.

Причини застосування перекладацьких синтаксичних трансформацій викликані відсутністю певних еквівалентів в українській мові, фіксований порядок членів речення англійської мови так як в українській він, порядок слів визначається відносною довільністю. Синтаксичні трансформації використовуються для передачі більш логічного смислу тексту оригіналу i зумовлені мовними нормами побудови синтаксичної одиниці [3].

Об'єднання речень - трансформація протилежна членуванню. Це спосіб перекладу при якому синтаксична структура в оригіналі перетворюється шляхом з'єднання двох чи більше простих речень[2]. Наприклад: 
(1) He began to say to himself: 'Perhaps I shall cross the River myself one day'. To which the other half of his mind always replied: 'Not yet' [J. R. R. T. ; c. 97].

Іноді він промовляв до себе: 'Мабуть, я теж колись перейду річку...', на щзо друга його половина душі відкликалась: 'коли-небудь пізніше... не тепер' [ B. M.; c. 108 ].

Отже, у прикладі (1) об'єднано два речення, що передають пряму мову. На наш погляд це було не обов'язковим, так як це призводить до важчого сприйняття тексту. Чим довше речення, тим важче його сприймати.

(2) But in the meantime, the general opinion in the neighbourhood was that Bilbo, who had always been rather cracked, had at last gone quite mad, and had run off into the Blue. There he had undoubtedly fallen into a pool or a river and come to a tragic but hardly an untimely, end [J.R. R. T.; c. 95].

Але в той час усі сусіди згодились, що Більбо й узагалі був трошки недоумкуватий, а згодом зовсім з глузду з'їхав $і$ чкурнув світ заочі, а там уже мабудь; звалився у який-небудь ставок чи річку, де знайшов свій, хоч $i$ сумний, але цілком вчасний кінеиь [В. М.; c. 76].

У прикладі (2) об'єднано два речення, які розділені між собою крапкою 3 комою. Перше містить у своєму складі три речення: S1 [But in the meantime, the general opinion in the neighbourhood was that] S2 [Bilbo had at last gone quite mad and had run off into the Blue] S3 [who had always been rather cracked]. У перекладі містяться всі ці три речення першого + друге, яке вміщує в собі ще два $\mathrm{S}^{1}$ [There he had undoubtedly fallen into a pool or a river] and $\mathrm{S}^{2}$ [undoubtedly fallen into a pool or a river]. На нашу думку таке з'єднання не досить прийнятне, так як чим довше речення тим важче його сприймати читачеві.

(3) He refused to go into mourning; and the next year he gave a party in honour of Bilbo's $112^{\text {th }}$ birthday, which he called a Hundred - weight Feast. But that was short of the mark, for twenty guests were in rited, and there were several meal sat which it snowed food and rained drink, a hobbits say [J. R. R. T.; c. 96].

Він відмовився носити жалобу за дядьком $i$ наступного року відсвяткував 112-у річнищю, хоча й досить скромно: запрочених було лише двадиять, зате до столу було подано гори наїдків та розливні озера напоїв, згідно з улюбленим прислів'ям гобітів [В. М.; с. 77].

На прикладі (3) показано як об'єднуються речення. У даному випадку, вони розділені таким розділовим знаком як двокрапка. Також у реченні присутня така синтаксична трансформація як вилучення: вилучено 'which he called a Hundred - weight Feast', і така трансформація як додавання: додано словосполучення 'згідно з улюбленим прислів'ям гобітів'.

Членування речення, має місце тоді коли одне складне речення перетворюється у низку з двох або більше речень. Речення членують на кілька менших тому що, це сприяє кращій читабельності тексту, так як 
читачеві буває важко орієнтуватися у логіко-смислових зв'язках компонентів таких складних речень [1]. Розглянемо членування речень на прикладі (39):

(39) As time went on, people began to notice that Frodo also showed signs of good 'preservation': outwardly he retained the appearance of a robust and energetic hobbits just out of his tweens [ J. R. R. T.; c. 97].

Минали роки, і народ помітив, що Фродо теж «непогано зберігся». Він не втратив вигляду міцного і бадьорого гобіта, який був десь у двадиять $\operatorname{sim}[$ B. M.; c. 78].

У прикладі (39) підрядне речення першотвору розділене на два простих речення у друготворі. Це дає змогу більш легшому читанню тексту. Що в свою чергу забезпечує легше сприйняття смислу тексту.

Отже, розглянувши всі чотири види трансформацій у простих реченнях i шість у складнопідрядних можна сказати, що перекладач частіше звертався до трансформацій додавання в обох типах речень. Так як англійська мова має фіксований порядок слів у реченні, перекладач вдається ще до такої синтаксичної трансформації як перестановка членів речення. В українській мові порядок слів у реченні вільний. Використовується трансформація заміни, щоб не було повторень, і в випадку нестачі прямих еквівалентів на українську мову.

Отже, англійська та українська мови мають різні типологічні характеристики, що зокрема проявляється у порядку слів (у порядку слідування членів речення), це спричиняє застосування перекладацьких синтаксичних трансформацій при відтворені аналітичної мови (англійська) флективною (українська). При перекладі складнопідрядних речень використовуємо синтаксичні трансформації: членування та об'єднання для кращого розуміння смислових зв'язків у романі, а отже і кращої читабельності у мові друготвору.

\section{Література:}

1. Мирам Г. С. Профессиональный перевод. Киев: «Эльга - Ника Центр». 2003. - 273 с.

2. Нешумаев И. В. Синтаксические трансформации при переводе английского текста на русский язык // Лингвистические и методические проблемы русского языка как неродного: Текст: структура и анализ. M. :1991. - C. 117-126.

3. Miram G. E. Translation Algorithms: Introduction to translation formalization. K. : 1998. $-276 \mathrm{p}$.

\section{Джерела ілюстративного матеріалу:}

1. B. M. : Джон Рональд Руел Толкін Володар Перснів / переклад 3 англійського В. Морозов - К. : Ранок, 2007. - 778 с. 
2. Джон Рональд Руэл Толкин Властелин колец / Джон Рональд Руэл Толкин, перевод с анг. В. Муравьев, А. Кистяковский - М. : Росмен, 2002. $-960 \mathrm{c}$.

3. J. R. R. T. : J. R. R. Tolkien The Lord of the Rings // The Fellowship of the Ring / J. R. R. Tolkien - M. : Рольф, 2001. - 288 c.

DOI https://doi.org/10.30525/978-9934-588-90-7-67

\title{
ПЕРЕКЛАДАЦЬКА СПАДЩИНА ЄВИ ГРІГАШ
}

\author{
др. Штефуца Вікторія, \\ дочент кафедри української мови та культури, \\ Ніредьгазький університет \\ м. Ніредьгаза, Угорщиина
}

Художній переклад функціонує як ланка міжмовної комунікації, яка зближує і збагачує культуру різних народів. У своєму дослідженні ми поставили перед собою завдання - представити угорську перекладачку Єву Грігаші, зібравши та проаналізувавши окремі видання іiі творів i праці, опубліковані в різних збірниках. Окрему увагу приділяємо при цьому вагомим фактам біографії авторки, що спричинилися до вибору життєвих та творчих пріоритетів.

Під час роботи над інтерпретацією тексту перекладач повинен досконало знати власну культуру та культуру народу, 3 мови якого здійснює переклад. Єва Грігаші, як білінгвіст, досконало знала обидві культури. Вона народилась у двомовній сім'ї і у своїх інтерв'ю завжди наголошувала: «Abban a szerencsés helyzetben vagyok, hogy édes anyanyelvemre fordíthatok apám nyelvéről. Apám ukrán, anyám magyar volt. Apámtól, mintegy ősforrásként hallottam a Kijevi Ruszról, anyámtól a Szent István-i Magyarországról. Ez a kettősség egyesült bennem, hiszen nem mondhattam le egyikükről sem» / «Мені пощастило, що я можу перекладати з мови батька на мою материнську рідну мову. Мій батько був українцем, а мати - угоркою. Від батька я чула про Київську Русь, від матері про Угорщину Святого Іштвана. Ця подвійність з'єднала мене, оскільки я не зреклась жодного з них» [4]. Сва Грігаші відмінно володіла українською, угорською, російською мовами та опанувала основу ієратики та ієрогліфів.

Початкову та середню освіту Єва Грігаші здобула в Ужгороді. Звідси

й почалось ознайомлення 3 літературою, a пізніше потяг до 